\title{
BIENVENIDOS A INCALAND. DAVID ROAS. PÁGINAS DE ESPUMA, 2014. P. 138.
}

José Güich Rodríguez (ULIMA)

Recebido em 18 ago 2015. José Güich Rodríguez (Lima, 1963). Licenciado en Aprovado em 10 nov 2015. Lingüística y Literatura por la Pontificia Universidad Católica del Perú. Profesor de Literatura de la Universidad de Lima. Es coautor de Ciudades ocultas: Lima en el cuento peruano moderno; En la comarca oscura. Lima en la poesía peruana. 1950-2000 y Umbrales y márgenes. El poema en prosa en el Perú contemporáneo, publicados por esa casa de estudios. Forma parte de una unidad de investigación del Programa de Estudios Generales de la Universidad de Lima. En 2011, obtuvo, con dicho colectivo, el segundo premio en el concurso de libros universitarios convocado por la Asamblea Nacional de Rectores. Asimismo, es narrador. Entre sus obras, figuran los volúmenes de cuentos El mascarón de proa (2006) y Control terrestre (2013), así como la novela El misterio del Barrio Chino (2013). Es crítico literario del diario limeño El Comercio. jguich@correo.ulima.edu.pe 
La literatura de viajes se convirtió en una práctica constante para los escritores europeos al iniciarse el siglo XIX. El paradigma romántico imponía, desde sus albores en la segunda mitad del XVIII, la experiencia del periplo a otras latitudes, ajenas pero atrayentes desde el punto de vista de las afinidades propias del movimiento respecto de los orígenes espirituales de la cultura occidental.

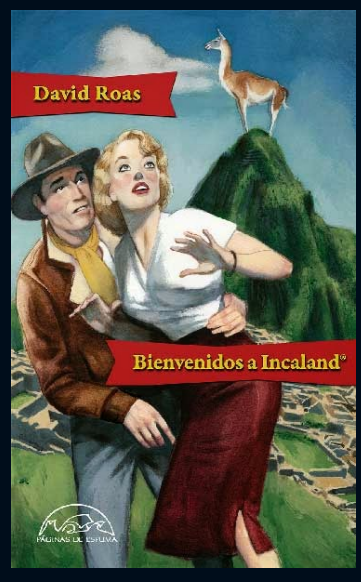
España e Italia fueron las locaciones preferidas por un buen número de autores que plasmaron en infinidad de libros todo lo observado y sentido durante sus visitas prolongadas a las regiones donde la "latinidad" había dejado sus huellas más visibles e imperecederas.

A medio camino entre el diario íntimo y la crónica, cada autor supo dar cuenta de aquello que el élan de esos países evocaba en sus conciencias -permeables a todos los estímulos- a través de la observación de las costumbres, la música, la comida y otras manifestaciones, especialmente las cultivadas por la gente sencilla - "buenos salvajes". En estas excursiones, que sondeaban lo popular como lo más cercano al genuino estado de naturaleza, no impregnado de los males de la "civilización", residía la motivación principal de los peregrinos, quizás los primeros turistas culturales en generar un discurso o una textualidad en torno al descubrimiento de la otredad. En ese aspecto, también se cumplía en gran medida el ideario del romanticismo temprano en torno de la comunión universal o de esa hermandad cósmica anunciada por Schiller. 
Las anteriores son algunas de las claves que permitirían situar Bienvenidos a Incaland ${ }^{1}$, del narrador catalán David Roas (Barcelona, 1965), dentro de alguna de las líneas genéricas dominantes en los sistemas literarios; por ejemplo, el viaje como un forma de conocimiento que va más allá del simple paseo por algún territorio exótico y del cual muchos retornan a sus tierras de origen con un concepto vago o impreciso, apoyado en la frivolidad del souvenir o de las fotos en las redes sociales. Por el contrario, Roas se ha propuesto una relectura de esa tradición y, al mismo tiempo, una crítica subrepticia e irónica a los modos burgueses -casi siempre frívolos o superficiales-, de articular su relación con lo foráneo.

Concebido como una suerte de camino de iniciación muy personal respecto al Perú como cifra a ser revelada -es decir, la tierra de los Incas que, en el imaginario global representa la riqueza áurea y el misterio inherente a un mundo ya desparecido-, el libro genera un relato particular que sugiere relaciones de intertextualidad con sus precedentes románticos, pero en un sentido cuestionador e inverso a los propósitos que los viajeros ya aludidos persiguieron a lo largo de sus jornadas.

A esa base, Roas añadirá diversos componentes expresivos, más próximos a los usos de representación de otras prácticas literarias, como lo absurdo, lo insólito, el terror e incluso lo fantástico, estéticas que también son sometidas a una mirada humorística en tanto el contexto observado exige el uso de todas esas herramientas para ser procesado. En otras palabras, se instala en la órbita de la ficción, más que del testimonio 
o recuerdo propiamente dicho. Con ello, también se articula una "suspensión" a propósito de las fronteras entre lo real o lo imaginado; ello convertiría a Bienvenido a Incaland en un volumen de narraciones más que en un proyecto autobiográfico.

La primera y breve sección, titulada sencillamente "Prólogo (Todo viaje necesita un)", da cuenta, recurriendo al narrador omnisciente y a la prospección, de lo que ese viajero hallará una vez arribado al aeropuerto de Lima. Se trata de un procedimiento que coloca a la voz narrativa en objeto de su propio horizonte de sucesos; en las siguientes secciones del libro, ese sujeto asume la primera persona. La anticipación de las ocurrencias principales que el viajero afrontará (o en las que participará, como el descabellado robo de la máquina de escribir de Vargas Llosa) prepara al lector y lo involucra en el registro desenfadado que el discurso asumirá como una de sus marcas relevantes. Un aspecto implícito en este umbral al relato o relatos es la dificultad de equiparar los códigos culturales del usuario extranjero y los del mundo caótico y anárquico por naturaleza que, más bien, ya le ha sido revelado, si entendemos que el prólogo se enuncia con posterioridad al viaje del cual ese sujeto enunciador ya ha retornado.

La segunda sección, "Lima" describe la inmersión del protagonista en la capital del país. Sus observaciones, dictadas por el asombro y la frustración -así como por el instinto de supervivencia- se centran en ángulos como el del ingobernable tráfico y lo pintoresco del servicio de transporte público, que parece desafiar principios físicos elementales. Pero lo más relevante es la aparición de escritores, miembros de su propio gremio, con quienes hilvana vínculos de complicidad; así mismo, 
ellos se convierten en guías tutelares, encargados de brindarle las armas intelectivas y conductuales indispensables para su desenvolvimiento autónomo en el tráfago cotidiano. Desde lo más anodino -cuánto debe pagarse por un servicio a taxistas sin tarifas fijas- hasta el ritual de asistir a uno de los bares más tradicionales o emblemáticos, como el Cordano -aledaño a la Plaza de Armas, sede de los poderes centrales-, cada escena está impregnada de un desconcierto que el sujeto narrativo incrementa con expresiones hiperbólicas. Ellas buscan, retóricamente, acentuar la atmósfera descoyuntada que caracteriza a los limeños y los transforma en seres identificados con la desorganización y la costumbre de actuar de manera opuesta a los patrones previsibles.

Incluso, la referencia a los sismos -a los cuales el visitante no está habituado- integra ese "cuadro o artículo de costumbres", otro género muy practicado en el siglo XIX, sobre todo en España. Desde la perspectiva del narrador, un ligero temblor implica una catástrofe de grandes proporciones, y quedará confundido ante la parsimonia de los limeños, a quienes observará desde la ventana de su alojamiento transitando con absoluta normalidad y sin inmutarse luego del fenómeno telúrico.

La tercera parte, "Cusco", prosigue el circuito obligatorio para todos los extranjeros; el destino decisivo es la antigua ciudad andina, ubicada en el sureste del territorio peruano. Punto neurálgico del turismo en distintas versiones (cultural, naturista o místico), su emblemático abolengo de capital histórica es refutado en cuanto el narrador asienta sus plantas en ese lugar. Su focalización, ya afectada por todos los episodios limeños -fusión de realidad y fantasía- se presenta aquí totalmente descoyuntada 
por aspectos también normales desde el punto de vista de los lugareños, pero insólitos y hasta sobrenaturales para un narrador a quien no se le brindan treguas o pausas que permitan la decodificación efectiva o coherente de todo lo surgido a su alrededor. Por ejemplo, la aparición de la niña cusqueña, ataviada con un traje típico, al parecer ubicua, que lo persigue sin desmayo por toda la ciudad exigiendo un pago monetario por un servicio no asumido o que él no contrató, pues tomó libremente una fotografía de ella, acompañada de un camélido. Es un empleo del que viven muchos habitantes, sumados al sistema de intercambio económico inducido por la presencia de miles de personas de diferentes latitudes. El efecto cómico se basa en la lucha por férreas convicciones personales: el narrador se niega a ceder posiciones; no pagará por la imagen obtenida en pleno ejercicio de su libertad. Cuando ya está seguro de haberse liberado del acoso, la pequeña irrumpe una vez más, debilitando sus barreras de contención sicológica, que en algún momento tendrán que derrumbarse ante la obstinada insistencia. En efecto, eso ocurre, hecho al que se sumará el inesperado el escupitajo del auquénido mientras la niña le entrega el cambio, que parece convertirse en la escena culminante de una tragicomedia. Este pasaje hilarante evoca también gran parte de la concepción común en torno de estos seres. También es objeto de ironización la presencia de otros visitantes de diversas nacionalidades, quienes convierten a la urbe en una suerte de remedo de sí misma, ataviados con la parafernalia asociada a lo típicamente "indígena", como es el uso de prendas llevadas por estos usuarios como señal de su "simbiosis" con el ambiente. 
En la mirada del narrador, estos personajes representan la apropiación de lo exótico por parte de Occidente, sin posibilidades de un sincretismo posible, porque está dictado por la superficialidad y el desaforado sentido del ridículo de los extranjeros frente a los nativos, quienes han sabido aprovechar, para su beneficio, todas las debilidades del "invasor", consumista irracional absorbido por los cosmético y no por los elementos más profundos de una cultura que ha sobrevivido a los embates de la globalización.

El episodio de la visita a Machu Picchu también se caracteriza por la presencia de un narrador aún desconcertado por todo lo que ve, pero con una ligera tendencia autodefensiva. Vive en un estado de alerta permanente ante los embates de la realidad. El diálogo con las referencias fílmicas y de la cultura popular, como la película de la década de 1950 titulada El secreto de los Incas, protagonizada por en aquel entonces aún desconocido Charlton Heston o las aventuras de Tintín, el famoso personaje del cómic francés, sirve de marco operacional y desmitificador. Los lugares comunes sobre la vieja civilización que esos soportes contribuyeron a fortalecer son igualmente diseccionados por el narrador-protagonista, quien termina, presionado por las tensiones del viaje, a emprender una especie de retirada estratégica que lo coloque a buen recaudo de los peligros.

El motivo de la llama como entidad diabólica que lo sigue, implacablemente, funge de hilo conductor: en Lima, vio también a uno de estos seres cuando se perdió en un intento infructuoso por retornar a su alojamiento sin recurrir a los medios de transporte públicos. Es un componente fantástico y desestabilizador, pero profundamente anclado en las experiencias concretas del viajero. La vivencia en torno 
de aquello que transgrede las leyes fácticas se nutre de la ambivalencia o incertidumbre frente a lo que el sujeto descentrado cree ver en una realidad engañosa y plagada de apariencias imposibles de una decodificación plena o sin ambivalencias.

En la "Coda", última sección del libro, hallamos al sujetonarrador en un vuelo aéreo, esta vez de retorno a su tierra de origen. La voz enunciadora asume esta vez el registro de segunda persona, a la manera de un distanciamiento de todo aquello que ha sido materia del trabajo de ficcionalización sobre el cual se han establecido las leyes del relato. De este modo, se configura una trayectoria inversa que reubicará al personaje en el orden quebrado durante el tiempo de su estancia en el Perú. La aparición inesperada de un "chullo", el estereotipado souvenir que llevan muchos extranjeros en la cabeza, es un recordatorio del limbo en el que ha estado viviendo, donde no es posible delimitar los territorios de lo real y de lo imaginado.

Bienvenidos a Incaland, con su estructura desmantelable en varias historias, pero unificadas en una búsqueda de totalidad significativa, pertenece a muchos dominios. Su autor, destacado cultor y estudioso de la literatura fantástica, al experimentar con las formas tradicionales, logra construir una trama verosímil cuya significación involucra tanto la crítica a las construcciones narrativas clásicas -en tanto modos de representación de esa otredad- como a un mundo en donde todo está tergiversado; subrepticiamente, las cosmovisiones originarias de los pueblos sometidos se resisten a desaparecer. Por eso, se amalgaman o fusionan con los elementos de la cultura hegemónica de un modo sutil o silencioso, aunque arriesgándose, al transformarse en 
objeto de intercambio utilitario, a perder una significativa zona de su esencia. No obstante, es una maniobra, hasta cierto punto, válida o legítima en un mundo cada vez más obsesionado por las redes planetarias y que poco a poco pierde aquello que hace de la humanidad algo único: su diversidad.

La propuesta es, por otro lado, un vehículo refutador de los excesos de la sociedad capitalista, desnaturalizadora por excelencia del acervo de los pueblos originarios. En este caso, los vericuetos de la fantasía desbocada funcionan como contrafuerte o paliativo de esas amenazas. Roas diseña, por lo tanto, una poética sustentada en la imaginación sin riendas como arma de contraofensiva frente a la manipulación orientada a neutralizar o adocenar a pueblos enteros bajo una prédica que no se ha despojado de los afanes colonialistas. Basta con el Mc Donald's de la Plaza Mayor del Cusco para comprobarlo. 